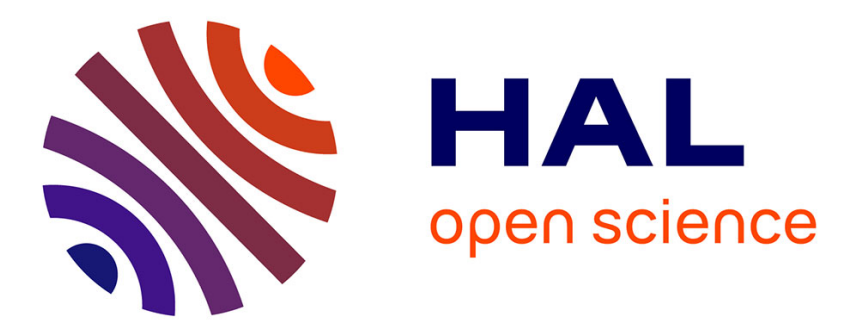

\title{
Chikungunya virus pathogenesis: From bedside to bench.
}

\author{
Thérèse Couderc, Marc Lecuit
}

\section{To cite this version:}

Thérèse Couderc, Marc Lecuit. Chikungunya virus pathogenesis: From bedside to bench.. Antiviral Research, 2015, 121, pp.120-31. 10.1016/j.antiviral.2015.07.002 . pasteur-01204785

\section{HAL Id: pasteur-01204785}

\section{https://hal-pasteur.archives-ouvertes.fr/pasteur-01204785}

Submitted on 24 Sep 2015

HAL is a multi-disciplinary open access archive for the deposit and dissemination of scientific research documents, whether they are published or not. The documents may come from teaching and research institutions in France or abroad, or from public or private research centers.
L'archive ouverte pluridisciplinaire HAL, est destinée au dépôt et à la diffusion de documents scientifiques de niveau recherche, publiés ou non, émanant des établissements d'enseignement et de recherche français ou étrangers, des laboratoires publics ou privés.

\section{(이) $\$$}

Distributed under a Creative Commons Attribution - NonCommercial - NoDerivatives| 4.0 


\section{Chikungunya virus pathogenesis:from bedside to bench}

Thérèse Couderc ${ }^{1,2}$, Marc Lecuit ${ }^{1,2,3,4}$

${ }^{1}$ Institut Pasteur, Biology of Infection Unit, Paris, France

${ }^{2}$ Inserm U1117, Paris, France

${ }^{3}$ Paris Descartes University, Sorbonne Paris Cité, Division of Infectious Diseases and Tropical

Medicine, Necker-Enfants Malades University Hospital, Institut Imagine, Paris, France

${ }^{4}$ Global Virus Network

\section{Highlights}

- Human chikungunya typically manifests as acute fever and joint pain

- Chikungunya can besevere, and associated with encephalitis, notably in neonates

- Chikungunya virus can cause chronic joint pain, and may induce arthritis

- Chikungunya virus infects fibroblasts in joints and muscles

- Type-I interferon sensing by non-myeloid cells is key to the control of chikungunya virus infection 


\section{Summary}

Chikungunya virus (CHIKV) is an arbovirus transmitted to humans by mosquito bite. CHIKV has caused a decade ago a major outbreak in the Island of the Indian Ocean, and then reached India and South East Asia. More recently, CHIKV has emerged in the Americas, first reaching the Caribbean and now extending to Central, South and North America. CHIKV is therefore considered as a major public health and economic threat. CHIKV causes febrile illness typically associated with debilitating joint pains. In rare cases, CHIKVmay also causes central nervous system disease, notably in neonates. Joint symptoms may persist for months to years, and lead to arthritis. This review focuses on the spectrum of symptomsassociated with CHIKV in human. It also illustrates how the analysis of human cohorts clinical and biological data and the development of animal and cellular models of infectionas helped identify the tissue and cell tropisms of the virus and decipher host responsesin benign, severe or persistent $\mathrm{CHIKV}$-associated disease.Please add the statement indicating that this is part of the symposium 


\section{Introduction}

Chikungunya virus (CHIKV) is a member of the Alphavirusgenus, belonging to theTogaviridae family. Several alphaviruses cause disease in humans. They are divided in two main phylogenetically distinct groups: one that causes arthralgia and/or arthritis, mainly found in the Old World and which includes CHIKV and its closest relative Semliki Forest virus (SFV), O'Nyong Nyong, Ross River (RRV), Barmah Forest(BFV); and one that causes encephalitis, mostlyfound in the New World and that includes western equine encephalitis and Venezuelan equine encephalitis viruses(for review see[44]). Sindbis virus (SINV), which is geographically restricted to the Old World, is howeverphylogenetically closer to the New World subgroup[44].Upon mosquito bite, CHIKV inducesan acute febrile illness typically accompanied by severe arthralgia, which can last and relapse for weeks to months. CHIKV has been the causeofseveral outbreaks in Africa, from where it originates and was first identified in the 50s, and in Asia. Since 2005, a new virus lineage(called Indian Ocean Lineage, IOL) that originated fromAfrica, has caused a massive outbreak in the Islands of the Indian Ocean, and reached India, South-East Asia, and also led to clusters of autochthonous cases in Southern Europe. Since the end of 2013, a strain of CHIKVoriginating from Asia has emergedthe Caribbean and spread to South, Central and North America[140, 141].

Here we reviewthe current knowledge on CHIKV infectionmainly obtained from the analysis ofcohorts of human patients and experimental animal models.

\section{Clinical presentation of chikungunya in human: more than a benign disease}

CHIKV infects human through the bite of mosquito vectors and causes disease called chikungunya, which means "walking bent" in Makonde, a language spoken in Austral Africa, where it was first identified (for review see[13, 87, 125, 126, 133, 141]). Its symptomsare similarto classical dengue fever, except that they are associated with intense arthralgia, which 
is strongly predictive of chikungunya. The incubation period is short, lasting about 2-4 days. In contrast to dengue fever, asymptomatic infections are rare; roughly $3-25 \%$ of people with serological evidence of infection have no obvious symptoms. CHIKV infection is usuallyselflimited, non-fatal, with fever resolving within a fewdays. However, since the Indian Ocean outbreak in 2005-2006[115], the information available about the clinical characteristics of the human disease has significantly increasedwith the detailed clinicalstudy of cohorts of CHIKV-infected patients, notably in the Island of La Réunion, a French overseas department[124]. Previously unreported severe forms of CHIKV infection were observed, as well as maternal-fetal transmission[28, 39, 102]. The most notable clinical feature of chikungunya is related to the fact that,following the acute phase, joint symptoms may persist for weeks to months with possibilities of relapses,leading to arthritis and some cases destructive rheumatism, with pathogenesis has yet to be fully understood[101].

\section{Chikungunya fever in humans}

The incubation period endswitha sudden onset of high fever $\left(>39^{\circ} \mathrm{C}\right)$, back pain, myalgia, associated tosevere and incapacitating arthralgia, together with headaches, photophobia, and rash (for a review see above).The onset of fever coincides with viremia, and bloodviral load can rapidly reach up to $10^{9}$ viral genome copies per milliliter[96, 124]. Viral replication triggers the activation of innate immune responses, the hallmark of which is the production of type I interferons (IFNs)[116].

Apositive correlation between the intensity of viremia and acute illnesshas been observed. Actually higher viral loads have been found in hospitalized patients with comorbidity than those without[124] and is most often associated with clinical symptoms than lower viral load[27]. However, other studies have reported that the viral load of symptomatic individuals doesnot differ with clinical presentation or co-morbidity, although ittends to be 
higher than in viremic asymptomatic individuals [5, 132].Several studies have alsoestablished that viral load is higher in newborns and the elderly[67, 124, 132].

Concomitant with viremia, the most common biological abnormality is leukopenia, and in particular lymphopenia[124], whichis more pronounced in patients with higher viremia[9].Other immunological markers associated with severe disease includenotably high levels of type-I IFNs, IL-1 $\beta$, IL-6, MCP-1 and $\mathrm{TNF} \alpha[60,90,137,139]$. Debilitating polyarthralgia isreported in the large majority of symptomatic patients, although children tend to displaymilder arthralgia[54]. Joint pain is typicallypolyarticular, bilateral, symmetrical and affects mainly the extremities (ankles, wrists, phalanges) but also larger joints (shoulders, elbows and knees)[75, 119, 122, 132].Joint symptoms can fluctuate in intensity, but do not usually varyanatomical location.Swelling may also occur in the interphalangeal joints, wrists, and ankles, as well as pain along ligament insertions, notably in children.Arthralgia experienced by CHIKV-infected patients closely resembles the symptoms induced by other viruses includingarthritogenic alphaviruses such as RRV and BFV [53, 126].Myalgia is alsofrequentlyobserved, its prevalence varying from one study to another[83, 124, 132], predominantly in the arms, thighs and calves.

During the acute stage of CHIKV infection, rash occurs in $10 \%$ to $40 \%$ of cases depending on the study[9, 28]. Itis characterized by transient macular or maculopapular rash that involves mainlythe extremities, but rarely the face, and lasts for 2-3 days. Children show a high prevalence of dermatological manifestations including hyperpigmentation,generalized erythema, maculopapular rash and vesiculobullous lesions[133, 135].

Rare ocular complications can occur during the acute illness, or with a delay,including uveitis, iridocyclitis, and retinitis[64, 72].

Less frequently, symptoms include lymphadenopathy, pruritus, and digestive abnormalities, which are more common after viremia has resolved[124, 145, 146]. 
Fever usually lasts less than a week, until viremia ends. This is the time whenpatients mountanti-CHIKV adaptive immunity,characterized by the appearance of anti-CHIKV antibodies[14].Joint symptoms usually resolve within 1-2 weeks, but a large proportion of patients exhibit persistent or relapsing arthralgia that lasts for months or years (see below).

It is notable that disease severity may depend on hosts and virus factors. The La Réunion isolate has been shown to replicate to higher level compared to botha West African lineage strain in rhesus macaquesand an Asian lineageisolate responsible for the recent Caribbeanoutbreak in a mouse model $[80,131]$. This may correlate with differences in terms of acute disease severity as well as prolongedsymptoms prevalence associated withIndian Oceanvs. West Africa and Asia lineages, respectively.

\section{Severe acute chikungunya in humans}

Severe CHIKVdisease in otherwise healthy individuals occurs mainly in the extreme ages, in elderly patients and young children.Adults with severe diseaseusually display underlying condition, such as diabetes, alcoholic hepatopathy, stroke, epilepsy, hypertension, or impaired renal function, which are independent risk factors for severe disease[28]. Severe disease can manifest as encephalopathy and encephalitis, cardiovascular and respiratory disorders, renal failure,hepatitis and myocarditis[9, 24, 28, 124].

Although CHIKV is not considered to beneurotropic, recent evidence suggests a neurological involvement in CHIKV infection, notably ininfected neonates and young children and the elderly, who appearmore prone to this complication. Most of the evidenceon CHIKV neurotropism stemfrom reports fromthe outbreaks due to IOL CHIKV strains, overthe past decade in La Réunion Island and India. Neurological presentationsmay include encephalitis, encephalopathy, acute flaccid paralysis, meningoencephalitisand Guillain-Barré syndrome[28, 104, 120, 144].Theanalysis of a cohort of CHIKV-infected patients with CHIKV RNA- or 
anti-CHIKV-IgM positive cerebrospinal fluid (CSF)shows that $42 \%$ of them fulfil the International Encephalitis Consortium criteriafor encephalitis[136],with an age distribution curve exhibiting a U-shaped pattern with a very clear trend towards the highest incidenceat the youngest age (Gérardinet al., unpublished).In young children, including neonates, neurological complications include encephalitis, seizures and acute encephalopathy.

Mother-to-child transmission of CHIKV infection wasfirst reported during the $\mathrm{La}$ Réunion outbreak, as a cause of severe neonatal disease, associated with neurological acute symptoms [39, 40, 46, 103]. The overall prevalence of maternal-fetal transmission is actually low (0.25\% after 22 weeks) [39], and vertical transmissionis observed exclusively in near-term deliveries in the context of intrapartum maternal viremia, with a rate that reached up to $50 \%$ during the La Reunion outbreak[39]. Whether host and viral genetic factors have an impact on mother-to-child transmission remains to be determined. The preventive role ofCaesarean section on transmission is not precisely known. During the La Reunion outbreak, severe illness was observed in $53 \%$ of infected neonatesand mainly consisted ofneurological signs [39]. Importantly,CHIKV infection in the perinatal periodcan cause severe diseasewith lifelong disability, as $51 \%$ of infected children exhibit global neurodevelopmental delay[40].

Detailed epidemiological investigations of maternal-fetal CHIKV transmission, as well as human placental and experimentalin vivoanimal studies have led to the conclusionthat vertical contamination most probably occurs as a consequence of passive transfer of maternal bloodfree CHIKV infectiousparticles through the placental barrier via the physiological breaches that arise at the term of pregnancy and during parturition, and which are known to lead to maternal-fetal blood exchanges[20, 39]. There is indeed no evidence that CHIKV actively infects and breaches the placental barrier, as for RRV[2, 81].

Hemorrhagic complications are exceptional, if they exist at all, and should therefore lead to the consideration of alternate diagnoses, such as a co-infection with DENV, or 
comorbidities such as chronic hepatopathy.

CHIKV-infected patients with severe disease often require hospitalization, in the context of their advanced age and loss of autonomy. Deaths due to the infection were documented for the first time during the 2005-2006 outbreak in La Réunion[28], and the most common causes of death were heart failure, multiple organ failure, hepatitis, and encephalitis. In epidemics that have occurred since 2005 , the case-fatality rateswere low, approximately 1 in $1,000[9,39,68,127]$.During CHIKV epidemics, a total of 260 excess deaths were reported in La Réunion island (mortality rate attributed to chikungunya 1/1,000)and a total of 2,944 excess deaths occurred in India (Ahmedabad) (mortality rate attributed to chikungunya $0.8 / 1,000)[56,78,79,98]$. Most of the deaths occurred in adults with underlying conditions, as well as, rarely, in neonates.

\section{Chronic chikungunya in human}

In contrast to the other symptoms that manifest at the acute phase, joint pain may persist, and relapse, for weeks to months and even years[36, 113, 121]. Long-lasting symptomsare typically not observed indengue fever, although asthenia can be intense in the days to weeks following the dengue fever. Chronic joint pain following chikungunya disease was first published in 1979[34] and has been massively reported during all recent epidemics that have occurred since 2005in the Indian Ocean notably in the Island of La Réunion[10, 52, 55, 76, 113, 121, 132]or in metropolitan France for imported cases[23, 66, 119], in India or Southeast Asia[36, 75, 89, 145], in Italy[84] and more recently in the Caribbean[32, 82]. Although the overall proportion of patients with chronic symptoms decreasesover time after CHIKV disease onset (from 100 to $88 \%$ during the first 6 weeks, to less than $50 \%$ after 3-5 years, with variable findingsdepending on the studies), the time required for a complete healing of all symptoms is still uncertain, as some infected individuals remain symptomatic 
for years post-infection[36, 113, 121].

Chikungunya chronic disease is characterized by persistent or relapsingarthralgia usually located at the same joint sites that were affected during the acute phase, and may mimic rheumatoid arthritis (chronic inflammatory, and rarely erosive and even deforming polyarthritis) $[36,55,113]$.

In a recent 6-year retrospective study on a cohort of patients in La Réunion, two main categories of post-chikungunya persisting rheumatic and musculoskeletal disorders were distinguished[55]:patients without previously defined arthritis who correspond to $27 \%$ of patients, and who present with currentmusculoskeletal disorders (loco-regional or diffuse), and patients withnon-crystalline polyarthritiswho represent $70 \%$ of patients fulfilling the diagnostic criteria of rheumatoid arthritis, spondyloarthritis or undifferentiated polyarthritis. The latter were refered toas patients with chronic inflammatory rheumatism (CIR). Among them, a minority (16\%) had pre-existing CIR that immediately exacerbated after CHIKV infection, while all the other developed CIR following CHIKV infection. As CIR may progress in a potentially destructive disease, early disease management by a specializedmedical team is important. Notably, early treatment with anti-inflammatory and immunosuppressive drugssuch as methotrexate might prevent joint damage, although their safety and efficacy remain to be validated in this context[55].

It is noteworthy that joints that are already damaged by underlying disorders, such as osteoarthritis seem to constitute preferential sites for long-term pain[121]. Of note, the likelihood of developing persistent arthralgia is highly dependent on age[55, 113].

This chronic disease has been reported to be associated with detectable IL-17 and elevated serum levels of IL-6 and granulocyte macrophage colony-stimulating factor in patients at 2-3 months after illness onset[19]. However, in a study conducted in patients with chronic symptomsup to 36 months after the acute phase, nosystemic biomarkers associated 
with chronic arthralgia nor biological markers typically found in autoimmune or rheumatoid diseases were reported[113].

Although the chronic disease generally causesless debilitatingpains than the acute disease, many patients still have a pronounced reduction in movement and quality of life and require long-term treatment[23, 84, 107, 113].

\section{Experimental CHIKV infection in animal models mimickingsome featuresof human}

\section{chikungunya}

Animal models for CHIKV infection, including mice and non-human primateshave been used to study CHIKV-associated pathologies[38]. A zebrafish animal model has also been developed and used to visualize CHIKV infection and innate host responses to infection[94]. However, most studies have been conductedin mice, including investigation on CHIKV tissue and cell tropisms, as well as host responses to infection.

Adult immunocompetent mice(wt mice) do not develop clinical signsfollowing intraperitoneal, intradermal orintravenousvirus inoculations[129].However, adult or 14-dayold C57BL/6 mice develop viremia and pathological changes after CHIKV inoculation via the subcutaneous route in the footpad, which are restricted to lesions inmuscles of the infected foot, leg swelling, edema with evidence of arthritis and tenosynovitis during the acute phase[37, 86].Moreover, newborn and 14-day-old outbread mice, and 8-9 day-old C57BL/6 are susceptible to $\mathrm{CHIKV}$ infection,either through the subcutaneous route in the loose skin of the back,or in the thorax via the intradermal route, respectively[20, 150]. They developviremia and skeletal muscle weakness that can be fatal in the case of younger mice and histopathological analysis of the affectedlimb reveals myositis with necrosis.

Adult mice with a complete deficiencyin the type-I interferon receptor (IFNAR ${ }^{-1}$ ) develop a severe infection after intra-dermal CHIKV inoculation and toa lesserextentafter 
ocular inoculation[20, 22]. The disease is characterized by muscle weakness of the limbs and lethargy, and is often fatal. Interestingly, adult mice with a partially abrogated type-I interferon receptor deficiency $\left(\operatorname{IFNAR}^{+-}\right.$) develop a mild disease without viremia but with a low level of replication in muscles and joints, indicating that the gene copynumber of the type-I IFNreceptorinfluences viral load andtissue distribution, as well as the severity of the disease[20].Therefore, young age and inefficient type-I IFN signalingare major factors of susceptibility to CHIKV severe disease in mice.

In contrast to adult wt mice, non-human primates are susceptible to CHIKV infection and this susceptibility has been reported since 1967, when rhesus monkeywere reported to be susceptible to experimental infection with CHIKVas evidenced by a febrile reaction and high levels of circulating virus[7]. More recently, studies performed in cynomolgus a (Macaca fascicularis) and rhesus (Macaca mulatta) macaquesexperimentally infected with CHIKV have shown thatinoculation via the intravenous route leads to systemic infection, with viremia levels of up to $10^{8} \mathrm{pfu} / \mathrm{mL}$, even if the infectious dose inoculated is low (10 PFU)[63, 80]. With the highest infectious dose $\left(10^{8} \mathrm{PFU}\right)$, monkeys developed clinical neurological disease characterized by meningo-encephalitis[63]. At the peak of viremia, leukopenia including lymphopenia is observed, similarly to lymphopenia observed in humans at the acute phase of the disease, as well as markers of type-I IFN response, inflammation, and cell immune activation[63].In macaques,CHIKV targets joints, secondary lymphoid organs, liver, and, to a lesser extent, muscle and skin. Interestingly, long-term CHIKV infection can beobserved, mainly in secondary lymphoid organs in cynomolgus macaques[63] and in aged rhesus macaques [80].Thus, the CHIKV-infected monkey provides an animal model to study these features of acute but also long-term evolution of chikungunya.

The lower susceptibility of mice as compared to humans or monkeys may involvespecies-specific factors. Actually, it has been shown that the human autophagy 
receptor NDP52 interacts with the CHIKV nonstructural protein $\mathrm{nsP} 2$, thereby promoting viral replication in human cell cultures, whereas the NDP52 mouse ortholog is unable to bind to nsP2 and to promote CHIKV infection in mouse cell cultures[58]. Thus, the absence of the proviral effect of NDP52 in the mouse may contribute to itslower permissiveness to CHIKV relative to humans. Whereas it is clear that an increased neonatal susceptibility is also observed in humans, the relevance of a type-I IFN defect and autophagy receptor NDP52 as a basis for severe infection in humans remains to be demonstrated.

Studies performed in animal models experimentally infected with CHIKV have alsocontributed to decipher the pathophysiology of the disease (see below).

\section{Resolved and pendingquestionsregarding thepathophysiology of CHIKV infection}

Whereas the pathophysiology of infection with other alphaviruses, such as SFV and SINVhas been studied for several decades, the pathophysiology of CHIKV infection has been investigated only over the last decade. The studies performedin naturally infected human and experimentally infected animal models have provided cluestothe cell and tissue tropisms of CHIKV,as well ashost factors that control infectionduringthe acute phase of infection.

\section{Cell and tissues tropisms of CHIKV}

\section{Acute phase of chikungunya disease}

The cell and tissue tropisms of CHIKV at the acute phase of the disease have been investigatedin humans and in animal models.Moreover, studies on CHIKV infection of cultures of primary cells and cell lines have also contributed to the deciphering of the cell biology of CHIKV infection.

In IFNAR ${ }^{-/-}$mice, CHIKV initially targetsthe liver, causes high viremia and replicates in connective tissues, particularly in the epimysium (also called muscle fascia) of skeletal 
muscle, in myo-tendinous insertions of muscle and in joint capsules, and to a lesser extent in the perimysium and endomysium of skeletal muscles[20]. Data in humans and infected muscle and joint tissues of mice showed that fibroblasts constitute major target cells of CHIKV at the acute phase of the infection. In mouse skeletal muscle, CHIKV canalso be detected, albeit rarely,in satellite cells, consistent with a study performed on human material[92]. Thus, CHIKV infection pathophysiology largely resembles to that of other arthritogenic alphaviruses, as the connective tissues of joints and skeletal muscles, and tendons are also the sites of replication of RRV and SINV[48, 85]. Of note, both joint and muscle connective tissues contains a high amount of nociceptive nerve-endings, and their stimulation upon infection may account for the muscle and joint pain characterizing disease caused by alphaviruses associated with muscle and joint pathology[21]. The pain triggered by joint mobilization may also result from the infection of musculo-tendinous insertions surrounding them.

Viral cell tropism in infected peripheral tissues of C57BL/6 mouse neonates, including muscleand joints, is similar to that of adult IFNAR $^{-/}$mice, with a pronounced tropism for fibroblasts[20]. A notable difference is the presence of severe necrotic myositis consistent with myofiber necrosis and inflammation manifested by the presence of infiltrates of lymphocytes and monocytes/macrophages. Similar data are found in young outbread mice[150]. Interestingly, in human adult muscle biopsies, myositis together with inflammatory infiltrates mainly consisting of monocytes/macrophages and $\mathrm{T}$ cells have been reported[92].Similarly to CHIKV in mouse neonates, RRV has been shown to induce myositis in mice $[48,85,110]$.

In the case of severe disease in mice, viremia is high and CHIKV also disseminatesto other tissues, including skin, eye and the central nervous system (CNS). CHIKV targets fibroblasts of deep dermis in the skin, as well as fibroblasts in the eye, including those of 
corneal and scleral stroma, corneal endothelium, ciliary body smooth muscle stroma, iris and those between ocular muscle fibers[20, 22]. In humans, CHIKV antigens have been found in fibroblasts of the same sites[20,22]. Uveitis is due to inflammation of the uvea (iris, ciliary body, and choroid), and histological data in CHIKV-infected ocular tissues may therefore provide a virological basis for uveitis, the main ocular manifestation associated with CHIKV infection[72, 102].

Together, these data demonstrate that infection of peripheral tissues responsible for symptomsin human in the context of acute CHIKV infection, i.e.joints, muscle, skin and eye, is restricted mainly to conjunctive tissues and the fibroblast as predominant target cell of CHIKV during acute infection. They also reveal that CHIKV and other arthritogenic alphaviruses share some tissue tropism similarities.

In vivo findingsareconsistent with thein vitro observation that human and mouse primary muscle fibroblasts, as well as primary human skin fibroblastsare susceptible to CHIKV infection[20, 29]. Fibroblasts derived from other tissues have also been shown to be permissive to $\mathrm{CHIKV}$, includinghuman lungfibroblasts, primary human foreskin fibroblasts, and mouse embryonic fibroblasts[111, 123]. These cells, as well as primary human skin fibroblasts, produce high level of IFN $\beta$ triggered by MAVS activation upon CHIKV infection[29, 111].It has been shown that infection of primary human skin fibroblasts triggers, in addition to IFN $\beta$, enhancement ofIL- $1 \beta$ expression,maturation of caspase- 1 and expression of the inflammasome sensor AIM2[29]. Moreover silencing of caspase-1 enhances viral replication. This suggests that $\mathrm{CHIKV}$-infected skin fibroblastsmay contribute to a proinflammatory and antiviral microenvironment[29].

The molecular basis for the prominent in vivo tropism for fibroblasts is unknown and may indicate thatfibroblasts could be, relative to other cell types, either $(i)$ in ahyperpermissive status regardingCHIKV entry/replication,and/or (ii) in a hypo-sensitive status to 
type-I IFN-mediatedviral interference, making them a target of choice for CHIKV[20].However, a study has shown that two human fibroblast cell lines with different susceptibility to CHIKV infection failed to showthat differences in the primary type-I IFN and IFN-stimulated genes (ISG)responses toCHIKV were responsible[134]. Alternatively, CHIKV cell-to-cell dissemination in fibroblasts may be dependent on the particular structure of connective tissues of dermis, joint capsules and muscles, that have in common the property to form a reticular network of cells interconnected by gap junctions[65].

Beside fibroblasts, monocytes/macrophages are another cell type possibly targeted by CHIKV. Actually, CHIKV antigens were detected in blood monocytes of acutely infected patients and monkeys early after infection[49, 106]. Primary human monocytes and macrophages could also be infected with CHIKV, although with low efficiency[123, 128] and in vivo,viral antigens were detected in monkey macrophages duringthe viremic phase of infection but also at later time points (6 weeks pi)[63], suggesting that they may either be a site of CHIKV replication, or of antigen clearance. These findings suggest that monocytes/macrophages might contribute to CHIKV physiopathology, although there contribution to viral load remains to be determined.

The susceptibility of monocytes/macrophages to CHIKV infection has been further investigated using in vitro models. A study revealed that CHIKV infection of human macrophage cell lines could be significantly increased by the presence of CHIKV-apoptotic blebs in the culture medium[61]. Another study showed that the murine macrophage cell line Raw264.7 can be infected by CHIKV butthat only a subset of cells is susceptible to infection and produce infectious particles, whereas the others appears to be refractory to infection[62].

Altogether these studies on monocytes/macrophages highlight the lower susceptibility of these cells to CHIKV, as compared to fibroblasts, which may involve cell specific host cellfactors determining the susceptibility and/or resistance to infection. Compared to 
monocytes, primary cultures of $\mathrm{B}$ and $\mathrm{T}$ cells were found not to be susceptible to CHIKV infection in vitro[49, 123, 128].

Other in vitro studies have highlighted the specific susceptibility or resistance of cells to $\mathrm{CHIKV}$ infection. CHIKV replicates in human muscle satellite cellsbut fails to infect differentiated myotubes[92], according to in vivo findings.Interestingly,human primary keratinocytes can be infected by CHIKV but viral RNA synthesis is impaired such as de novo viral particle are not produced, suggestingan intracellular block of CHIKV replication in human keratinocytes[6]. According to this finding, the replication of CHIKV in keratinocytes in vivo has thus far never been reported.In vitro, mouse embryonic stem cellsare susceptible to CHIKV infection andsense type I IFNs, butto a lower extent than CHIKV-infected fibroblasts. Moreover, theyare deficient in type I-IFN expression, as compared toCHIKVinfected fibroblasts[138]. Given the relative deficiency of stem cells to produce and respond to type-I IFN, they may constitute an important target for CHIKV in vivo, and may have a relevance for the long term consequences of infection.

\section{Severe acutechikungunya disease}

In the CNS of experimentally infected highly susceptible mice, CHIKV targets the choroid plexuses, meningeal and ependymal envelopes, but brain microvessels and parenchyma are spared in neonates, adult $\mathrm{IFNAR}^{-/}$mice, as well as in adult infected monkeys[20, 150]. Primary mouse choroid plexus epithelial cells were highly susceptible to infection, while primary mouse brain microvessel endothelial cells were fully resistant to CHIKV infection[20].In humans,CHIKV and anti-CHIKV IgMs have been detected in the CSF of neonates and adult patients with CNS symptoms[45].Altogether, these data suggest that CHIKV may infect and cross the blood-brain barrier at the choroid plexus and leptomeningeal levels and then infects CNS envelopes. In monkeys, high levels of cytokines 
are found to be associated with encephalopathy[63]. Thus, the cytopathic effects induced in infected cells of brain envelopes and the host responses triggered, may affect underlying neuronal cells, leading to the CNS signs and symptoms associated with neurologic symptoms. In contrast to adult animals, a recent study has shown that CHIKV infects parenchymalcellsin neonatal/suckling micebut the nature of these cells is unknown[26]. A defective host response may contribute to $\mathrm{CHIKV}$ neurotropism in neonates, as well as to the generallyhigher susceptibility of neonates to severe CHIKV infection, in agreement withthe fact that the neonatal immune response is quantitatively and qualitatively distinct from that of adults[3]. In vitro studies show that CHIKV replicates inmouse astrocytes and oligodendrocytes, and with lower efficacy in neuronal cells but fails to infect microglia [25]. Further studies will be needed to fully decipher CHIKV tissue and cell neurotropism. In contrast, it is well established that New World alphaviruses cause encephalitis in humans and in animal models as a consequence of viral invasion of the brain microvessels and parenchyma[31, 147].

Mother-to-child CHIKV transmission has been studied in experimental infection of pregnant animals. Investigation of mouse and human placentas from viremic mothers have shown that, in contrast to SFV and RRV, CHIKV does not directly infect trophoblastic cells andis therefore probably transmitted to neonates through maternal-fetal blood exchange during delivery, accounting for the low frequency of mother-to-child transmission before near term delivery[1, 20, 81].

\section{Chronic phase of chikungunya disease}

The pathophysiology of CHIKV chronic disease remainspoorly understood and, to date, no animal model fully reproduces the chronic jointsyndrome associated with many cases. In humans, patients with chronic CHIKV-induced arthralgia often have persistent virus-specific IgM[10, 74], that could result from continued exposure to CHIKV antigen. One 
study has provided evidence for persistence of viral antigen and RNA in synovial tissue from a patient with chronic arthralgia for 18 months after CHIKV infection[52]. In animal models, persistence of viral RNA has been shown both in mice and in monkeys. In mice, viral RNA can be detected in joint-associated tissues for at least 16 weeks following footpad injection and is associated with histopathological evidence of joint inflammation[47, 100]. Interestingly, onestudy has demonstrated that viral RNA persists in lymphoid organs and liver and, to a lesser extent, in muscle and joints ofmacaques, and identified macrophages as the main cellular reservoirs during the late stages of CHIKV infection[16, 51, 63], suggesting that macrophages play also a role in chronic disease. Viral RNA persistence in both one human case and CHIKV animal models raises the question of the role of CHIKV RNA in joint inflammation and injury, as it has been shown that double strandedRNA, a product of viral genome replication, is arthrithogenic[148].

In addition to IgM, patients with chronic joint pains can display elevated IL-6 levels[15, 19, 105]. For RRV, it has been shown that infection of osteoblasts results in increased of IL-6 together with a change of the ratio of Receptor Activator of Nuclear FactorKappaB Ligand(RANKL) to osteoprotegerin (OPG), which have been implicated in bone disease including arthritis and osteoporose[17]. In mouse models, infectious RRV isdetectedin bones and a reduction of bone volumes is observed inassociation with adisruption of the ratio of RANKL/OPG. Importantly, the bone loss caused by RRV infection in mice, as well as the changes in the ratio RANKL/OPG are prevented by IL-6 inhibition[17]. These findings suggest a mechanism involving direct infection of osteoblasts to explain joint pathologies during infection with RRV and possibly CHIKV[12]. As for RRV, pre-existing arthritis is exacerbated by CHIKV infection[55] and the inflammatory response during alphavirus infection in the joint is similar to that in rheumatoid arthritis, with a similar pattern of leukocytes infiltration, cytokine production and complement activation[13, 88, 
117].Deciphering the viral and immune mechanisms leading tojoint pathologiesis a health concern, notably in the case of pre-existing arthritis given the relatively high incidence of bone disease in the general population.

\section{Host responseto CHIKV infection}

Studies in humans and animal models have shownthat innate immunity, and particularly the type-I IFN response, is crucial for restricting virus replication during the acute phase of infection. Moreover, as mentioned above, antibodies against CHIKV are present in the serum of infected humans at the end of viremia.

\section{Innate responseto $\mathrm{CHIKV}$ infection}

Alphaviruses, including CHIKV, are long known to be strong inducers of type-I IFN and sensitive to type-I IFN responses[30, 41, 43].More recent studies in patients in La Réunion also reported that CHIKV infection elicited high levels ofIFN- $\alpha$ in the serum and its concentration correlatedwith viral load[111, 139].Similar to human patients, the acute disease in monkeys is associated withsubstantially increased type-I IFNconcentration in the plasma[63].As in mammals, CHIKV infection triggers a strong type-I IFN response, critical for survival in CHIKV-infected zebrafish[94].

Recently, the roles of type-I IFNin CHIKV infection and its related antiviral pathways have been deciphered.As mentioned above, adult IFNAR ${ }^{-/-}$mice are fully susceptible to sever CHIKV infection, in contrast to adult wt mice. Interestingly, it has been shown that thisabsence of susceptibility upon intradermal infection of wt mice is due to the very early control of CHIKV infection by type-I IFN at the site of injection in the skin. Actually,infection is rapidly controlled by IFN- $\beta$ secreted locally by infected dermal fibroblasts, whichleads to antiviral response at the site of injection[111].It is notable that no 
other cell type, including hematopoietic cells, is infected at the injection site in wt adult mice.

The role of type-I IFN in CHIKV pathogenesis has been investigated further in humans and in mouse models, as well as in human cells. In mice, it has been demonstrated that CHIKV is controlled by the direct action of type-IIFN on nonhematopoietic cells[111], and nonhematopoietic cell-derived type I-IFN is sufficient to control CHIKV infection[112]. Moreover, the production of type I-IFN by nonhematopoietic cells acts via an MAVSdependent signaling pathway likely triggered by activation of host sensors (RIG-I and/or MDA5) for CHIKV RNA in infected fibroblasts[108, 111, 112, 143]. It has also been shown that IRF-3 or IRF-7 expression in either hematopoietic or nonhemotopoietic cell compartments is capable of inducing an antiviral response. Moreover, IRF-3 or IRF-7 signaling is sufficient to control CHIKV in adult mice, whereas both transcription factors are required in mouse neonates[112]. These findings indicate that IRF-3 and IRF-7 play an essential role in the control of neonatal CHIKV infection in mice and highlight an agedependent redundancy for IRF-3 or IRF-7 in adult but not newborn animals.

Type-I IFN is able to trigger the activation of a specific signal transduction pathway leading to induction of ISGs that are responsible for the establishment of an antiviral state.ISGs that have been found to exert an antiviral role against CHIKV in vitro and/or in vivo includeISG15, ISG20, P56, ZAP, OAS3 andViperin[11, 69, 71, 142, 149].

The role of monocytes/macrophages in CHIKV disease has also been investigated in the acute phase of the disease. Studies with non-human primate and mouse models also suggest that viral replication in joint tissues leads to the recruitment of inflammatory cells, with monocytes, macrophages, and natural killer cells being the major inflammatory cell types[37, 63].Consistent with the role of monocytes/macrophages in inflammation during the acute disease are studies showing that macrophage depletion in mice reducesfoot swelling induced by injection of CHIKV in the footpad. Consistent with this observation, treatment 
with Bindarit, an inhibitor of monocyte chemoattractant protein-1 (MCP-1) chemokine (CCL2) production, blocksmonocytes recruitment and reducesjoint inflammation in mice[18, 37, 109]. However, the recruitment of monocytes/macrophages also appears to be critical for preventing excessive pathology and resolving inflammation, as $\mathrm{CHIKV}$-infection in $\mathrm{CCR} 2^{-/-}$deficient mice with a defective CCL2 receptorresultsin more severe disease due to an excessive recruitment of neutrophils rather than monocytes/macrophages to the inflamed joint[99].

These data provide evidence that monocytes/macrophages are involved in the pathophysiology of CHIKV acute disease. As mentioned above, some of them seem to be targeted by CHIKV. Further studies will be required to clarify the relationship between their role as target cells and as innate immune cells together with their role in inflammation duringthe acute phase of the disease.

Autophagy has been shown to be an innate mechanism involved in host response to CHIKV infection.Actually, Atg16L(HM) mice, which display reduced levels of autophagy, showeda higher sensitivity to CHIKV-induced apoptosis and exhibited increased lethality, suggesting that inducers of autophagy inhibits apoptosis and may limit the pathogenesis of acute chikungunya[57].

Besides innate response, CHIKV infection also leads to a protective adaptive immunity.

\section{Adaptive immunityto CHIKV infection}

Anti-CHIKV immunoglobulin M (IgM) and immunoglobulin G (IgG) are detected in the sera of infected patients during the acute phase of disease[59, 83, 91, 95]. These antibodies exhibit a high in vitro neutralizing activity and in vivo studies have demonstrated the importance of anti-CHIKV neutralizing antibodies in the protection against CHIKV 
infection (see below, Immunotherapy).The protective role of antibody in CHIKV infectionis also illustrated by the reportthatinfected mice deficient for TLR3 signaling synthesizeantiCHIKV antibodies that exhibit a lower in vitro neutralization potency than those generated in wt mice[50].

The role of $\mathrm{B}$ and $\mathrm{T}$ cells has been investigated in $\operatorname{Rag} 1^{-/}$mice, which lack $\mathrm{T}$ and $\mathrm{B}$ cells. After infection in the footpad, $\operatorname{Ragl}^{-/-}$mice display higher viral levels in a variety of tissues than wt mice, suggesting that adaptive immunity controls the tissue specificity and helps clear CHIKV infection[47]. The role of B cells was also explored in B cell deficient $(\mu \mathrm{MT})$ knockout mice infected with $\mathrm{CHIKV}$ in the footpad. In these animals, viremia persisted for over a year, indicating a direct role for B cells and antibody in mediating CHIKV clearance[70, 100]. Moreover, theseinfected mice exhibited a more severe disease than wildtype mice during the acute phase. The roles of $\mathrm{T}$ cells were explored in adult mice deficient for $\mathrm{T}$ cells and infected in the footpad. Interestingly, it was found that $\mathrm{CHIKV}$-specific $\mathrm{CD}^{+}{ }^{+}$but not $\mathrm{CD}^{+} \mathrm{T}$ cells are essential for the development of joint swelling without any effect on virus replication and dissemination, suggesting $\mathrm{T}$ cells are involved in inflammation[47, 130]. This corroborates observationsmade fromhuman muscle biopsies where $\mathrm{T}$ cells, but not $\mathrm{B}$ cells, were detected[92].

The importance of $\mathrm{B}$ and $\mathrm{T}$ cells in protection against CHIKV infections has also been demonstrated by vaccine studies[73]. Actually, vaccination against CHIKV is able to induce a strong CD8+T cell-mediated cellular response as well as a humoral response that protects mouse and nonhuman primate models against a lethal challenge[73, 97].

Finally, the role of hostage on the $\mathrm{T}$ and $\mathrm{B}$ cell responses has been investigated in rhesus macaques. Interestingly, aged animals have delayed and/or reduced $\mathrm{T}$ and $\mathrm{B}$ cell immunity compared to adult animals [80]. Moreover, while adult animals are able to control viralinfection, aged animals show persistent virus in the spleen. These data support clinical 
findings of CHIKV susceptibility in elderly humans and provide evidence that an effective T and B cell responses against the virus are required for preventing persistent CHIKV infection.

\section{Immunotherapy}

The protective effect of passive immunization against alphaviruses, including Venezuelan Equine Encephalitis virus, SINV and SFV, was long ago demonstrated in mouse models a long time ago[8, 77, 114]. In recent years, passive immunization has beeninvestigated in mouse models susceptible to CHIKV infection. The first study reporting the use of passive immunization against CHIKV was performed with human polyvalent antibodies purified from human plasma donors in the convalescent phase of CHIKV infection[21]. These antibodies exhibited strong neutralizing activity in vitro and had a full protective efficacy in highly susceptible mouse models: adult IFNAR ${ }^{-/-}$mice and neonatal C57BL/6 mice. Moreover, they displayed a therapeutic efficacy in these animal models when administrated after infection. Similarly, purified polyclonal antibodies from monkeys immunized with a CHIKV virus-like particle vaccine protected $\mathrm{IFNAR}^{-/-}$mice from CHIKVinduced disease and death[4].

As for neutralizing polyclonal antibodies, human and mouse neutralizing monoclonal antibodies have been shown to protect mice against CHIKV. Human neutralizing monoclonal antibodies directed against E2 or E1 significantly delay lethality of CHIKV-infected mice, both in prophylactic or therapeutic settings[33, 35]. Similarly, a human neutralizing monoclonal antibody directed against E2 protein is able to prophylactically protect adult C57BL/6 mice from viremia and foot swelling, and to therapeutically protect neonatal C57BL/6 mice from death[118]. In other studies, mouse neutralizing antibodies directed against the E1 or E2 protein have been shown to provideboth prophylactic protection from viremia and foot swelling of adult C57BL/6 mice and fromCHIKV-induced lethality in adult 
$\mathrm{IFNAR}^{-/-}$mice[42, 93]. Interestingly, combinations of twoneutralizing monoclonal antibody administrated after CHIKV infection completely prevent mortality of IFNAR $^{-/-}$mice.

Altogether, these studies suggest that passive immunization may constitute an effective medical intervention for humans with a known exposure to CHIKV who are at risk forsevere disease. This prophylaxis approach could thus be recommended especially during birth for neonates born to viremic mothers, who are at high risk of developing severe infection[39]. The protective role of anti-CHIKV hyperimmune human intravenous immunoglobulins in neonates exposed to a high risk of severe form of CHIKVinfection is currently under clinical investigation (see ClinicalTrials.gov number NCT02230163).

These data on the protective role of neutralizing antibodies against CHIKV disease should be taken into account in the design of an efficient vaccine against CHIKV.

\section{Conclusions}

Repeated, massive CHIKV repeated massive outbreaks of the last decade have elucidatedmany new facets of CHIKV infection, including detailed clinical analysis of chronic debilitating arthragia and severe disease. Chikungunya can no longer be considered as a purely benign, self-limited disease. Studies performed in patients and animal models have provided the first data on the pathophysiology of infection and have shown the similarities and differences with other alphaviruses, as well as with dengue virus infection. However, many questions remain to be resolved, particularly the susceptibility and the role of immune cells in the acute and chronic disease and the neurotropism of CHIKV infection.Increased basic and translational research, with access to tissues and cells from infected patients, will be key to answer these questions and identify all the host and viral factors involved in the susceptibility of the host, tissue and cell to CHIKV. This research will allow us tobetter prevent and treat the chronic and/or severe diseases caused by CHIKV. 


\section{References}

1. Aaskov JG, Davies CE, Tucker M, Dalglish D (1981) Effect on mice of infection during pregnancy with three Australian arboviruses. Am J Trop Med Hyg 30:198-203

2. Aaskov JG, Nair K, Lawrence GW, Dalglish DA, Tucker M (1981) Evidence for transplacental transmission of Ross River virus in humans. Med J Aust 2:20-21

3. Adkins B, Leclerc C, Marshall-Clarke S (2004) Neonatal adaptive immunity comes of age. Nat Rev Immunol 4:553-564

4. Akahata W, Yang ZY, Andersen H, Sun S, Holdaway HA, Kong WP, Lewis MG, Higgs S, Rossmann MG, Rao S, Nabel GJ (2010) A virus-like particle vaccine for epidemic Chikungunya virus protects nonhuman primates against infection. Nat Med 16:334-338

5. Appassakij H, Khuntikij P, Kemapunmanus M, Wutthanarungsan R, Silpapojakul K (2013) Viremic profiles in asymptomatic and symptomatic chikungunya fever: a blood transfusion threat? Transfusion 53:2567-2574

6. Bernard E, Hamel R, Neyret A, Ekchariyawat P, Moles JP, Simmons G, Chazal N, Despres P, Misse D, Briant L (2015) Human keratinocytes restrict chikungunya virus replication at a post-fusion step. Virology 476:1-10

7. Binn LN, Harrison VR, Randall R (1967) Patterns of viremia and antibody observed in rhesus monkeys inoculated with chikungunya and other serologically related group A arboviruses. Am J Trop Med Hyg 16:782-785

8. Boere WA, Benaissa-Trouw BJ, Harmsen M, Kraaijeveld CA, Snippe H (1983) Neutralizing and non-neutralizing monoclonal antibodies to the E2 glycoprotein of Semliki Forest virus can protect mice from lethal encephalitis. J Gen Virol $64(\mathrm{Pt}$ 6):1405-1408

9. Borgherini G, Poubeau P, Staikowsky F, Lory M, Le Moullec N, Becquart JP, Wengling C, Michault A, Paganin F (2007) Outbreak of chikungunya on Reunion Island: early clinical and laboratory features in 157 adult patients. Clin Infect Dis 44:1401-1407

10. Borgherini G, Poubeau P, Jossaume A, Gouix A, Cotte L, Michault A, Arvin-Berod C, Paganin F (2008) Persistent arthralgia associated with chikungunya virus: a study of 88 adult patients on reunion island. Clin Infect Dis 47:469-475

11. Brehin AC, Casademont I, Frenkiel MP, Julier C, Sakuntabhai A, Despres P (2009) The large form of human 2',5'-Oligoadenylate Synthetase (OAS3) exerts antiviral effect against Chikungunya virus. Virology 384:216-222

12. Burt F, Chen W, Mahalingam S (2014) Chikungunya virus and arthritic disease. Lancet Infect Dis 14:789-790

13. Burt FJ, Rolph MS, Rulli NE, Mahalingam S, Heise MT (2012) Chikungunya: a reemerging virus. Lancet 379:662-671

14. Carey DE, Myers RM, DeRanitz CM, Jadhav M, Reuben R (1969) The 1964 chikungunya epidemic at Vellore, South India, including observations on concurrent dengue. Trans R Soc Trop Med Hyg 63:434-445

15. Chaaitanya IK, Muruganandam N, Sundaram SG, Kawalekar O, Sugunan AP, Manimunda SP, Ghosal SR, Muthumani K, Vijayachari P (2011) Role of proinflammatory cytokines and chemokines in chronic arthropathy in CHIKV infection. Viral Immunol 24:265-271

16. Chen CI, Clark DC, Pesavento P, Lerche NW, Luciw PA, Reisen WK, Brault AC (2010) Comparative pathogenesis of epidemic and enzootic Chikungunya viruses in a pregnant Rhesus macaque model. Am J Trop Med Hyg 83:1249-1258 
17. Chen W, Foo SS, Rulli NE, Taylor A, Sheng KC, Herrero LJ, Herring BL, Lidbury BA, Li RW, Walsh NC, Sims NA, Smith PN, Mahalingam S (2014) Arthritogenic alphaviral infection perturbs osteoblast function and triggers pathologic bone loss. Proceedings of the National Academy of Sciences of the United States of America 111:6040-6045

18. Chen W, Foo SS, Taylor A, Lulla A, Merits A, Hueston L, Forwood MR, Walsh NC, Sims NA, Herrero LJ, Mahalingam S (2015) Bindarit, an inhibitor of monocyte chemotactic protein synthesis, protects against bone loss induced by chikungunya virus infection. J Virol 89:581-593

19. Chow A, Her Z, Ong EK, Chen JM, Dimatatac F, Kwek DJ, Barkham T, Yang H, Renia L, Leo YS, Ng LF (2011) Persistent arthralgia induced by Chikungunya virus infection is associated with interleukin-6 and granulocyte macrophage colonystimulating factor. J Infect Dis 203:149-157

20. Couderc T, Chrétien F, Schilte C, Disson O, Brigitte M, Guivel-Benhassine F, Touret Y, Barau G, Schuffenecker I, Desprès P, Arenzana-Seisdedos F, Michault A, Albert A, Lecuit M (2008) A mouse model for Chikungunya: young age and inefficient typeI interferon signaling are risk factors for severe disease. PLoS Pathog 4:e29

21. Couderc T, Khandoudi N, Grandadam M, Visse C, Gangneux N, Bagot S, Prost JF, Lecuit M (2009) Prophylaxis and therapy for Chikungunya virus infection. J Infect Dis 200:516-523

22. Couderc T, Gangneux N, Chretien F, Caro V, Le Luong T, Ducloux B, Tolou H, Lecuit M, Grandadam M (2012) Chikungunya virus infection of corneal grafts. J Infect Dis 206:851-859

23. Couturier E, Guillemin F, Mura M, Leon L, Virion JM, Letort MJ, De Valk H, Simon F, Vaillant V (2012) Impaired quality of life after chikungunya virus infection: a 2year follow-up study. Rheumatology (Oxford) 51:1315-1322

24. Das T, Jaffar-Bandjee MC, Hoarau JJ, Krejbich Trotot P, Denizot M, Lee-Pat-Yuen G, Sahoo R, Guiraud P, Ramful D, Robin S, Alessandri JL, Gauzere BA, Gasque P (2010) Chikungunya fever: CNS infection and pathologies of a re-emerging arbovirus. Prog Neurobiol 91:121-129

25. Das T, Hoarau JJ, Jaffar Bandjee MC, Maquart M, Gasque P (2015) Multifaceted innate immune responses engaged by astrocytes, microglia and resident dendritic cells against Chikungunya neuroinfection. J Gen Virol 96:294-310

26. Dhanwani R, Khan M, Alam SI, Rao PV, Parida M (2011) Differential proteome analysis of Chikungunya virus-infected new-born mice tissues reveal implication of stress, inflammatory and apoptotic pathways in disease pathogenesis. Proteomics 11:1936-1951

27. Dutta SK, Pal T, Saha B, Mandal S, Tripathi A (2014) Copy number variation of Chikungunya ECSA virus with disease symptoms among Indian patients. J Med Virol 86:1386-1392

28. Economopoulou A, Dominguez M, Helynck B, Sissoko D, Wichmann O, Quenel P, Germonneau P, Quatresous I (2009) Atypical Chikungunya virus infections: clinical manifestations, mortality and risk factors for severe disease during the 2005-2006 outbreak on Reunion. Epidemiol Infect 137:534-541

29. Ekchariyawat P, Hamel R, Bernard E, Wichit S, Surasombatpattana P, Talignani L, Thomas F, Choumet V, Yssel H, Despres P, Briant L, Misse D (2015) Inflammasome signaling pathways exert antiviral effect against Chikungunya virus in human dermal fibroblasts. Infect Genet Evol 32:401-408

30. Farber PA, Glasgow LA (1972) Effect of Corynebacterium acnes on interferon production in mice. Infect Immun 6:272-276 
31. Ferguson MC, Saul S, Fragkoudis R, Weisheit S, Cox J, Patabendige A, Sherwood K, Watson M, Merits A, Fazakerley JK (2015) The ability of the encephalitic arbovirus Semliki Forest virus to cross the blood brain barrier is determined by the charge of the E2 glycoprotein. J Virol

32. Foissac M, Javelle E, Ray S, Guerin B, Simon F (2015) Post-Chikungunya rheumatoid arthritis, Saint Martin. Emerg Infect Dis 21:530-532

33. Fong RH, Banik SS, Mattia K, Barnes T, Tucker D, Liss N, Lu K, Selvarajah S, Srinivasan S, Mabila M, Miller A, Muench MO, Michault A, Rucker JB, Paes C, Simmons G, Kahle KM, Doranz BJ (2014) Exposure of epitope residues on the outer face of the chikungunya virus envelope trimer determines antibody neutralizing efficacy. J Virol 88:14364-14379

34. Fourie ED, Morrison JG (1979) Rheumatoid arthritic syndrome after chikungunya fever. S Afr Med J 56:130-132

35. Fric J, Bertin-Maghit S, Wang CI, Nardin A, Warter L (2013) Use of human monoclonal antibodies to treat Chikungunya virus infection. J Infect Dis 207:319-322

36. Ganu MA, Ganu AS (2011) Post-chikungunya chronic arthritis--our experience with DMARDs over two year follow up. J Assoc Physicians India 59:83-86

37. Gardner J, Anraku I, Le TT, Larcher T, Major L, Roques P, Schroder WA, Higgs S, Suhrbier A (2010) Chikungunya virus arthritis in adult wild-type mice. J Virol 84:8021-8032

38. Gasque P, Couderc T, Lecuit M, Roques P, Ng LF (2015) Chikungunya virus pathogenesis and immunity. Vector borne and zoonotic diseases 15:241-249

39. Gerardin P, Barau G, Michault A, Bintner M, Randrianaivo H, Choker G, Lenglet Y, Touret Y, Bouveret A, Grivard P, Le Roux K, Blanc S, Schuffenecker I, Couderc T, Arenzana-Seisdedos F, Lecuit M, Robillard PY (2008) Multidisciplinary prospective study of mother-to-child chikungunya virus infections on the island of La Reunion. PLoS Med 5:e60

40. Gerardin P, Samperiz S, Ramful D, Boumahni B, Bintner M, Alessandri JL, Carbonnier M, Tiran-Rajaoefera I, Beullier G, Boya I, Noormahomed T, Okoi J, Rollot O, Cotte L, Jaffar-Bandjee MC, Michault A, Favier F, Kaminski M, Fourmaintraux A, Fritel X (2014) Neurocognitive outcome of children exposed to perinatal mother-to-child Chikungunya virus infection: the CHIMERE cohort study on Reunion Island. PLoS Negl Trop Dis 8:e2996

41. Glasgow LA, Odugbemi T, Dwyer P, Ritterson AL (1971) Eperythrozoon coccoides. I. Effect on the interferon response in mice. Infect Immun 4:425-430

42. Goh LY, Hobson-Peters J, Prow NA, Gardner J, Bielefeldt-Ohmann H, Pyke AT, Suhrbier A, Hall RA (2013) Neutralizing monoclonal antibodies to the E2 protein of chikungunya virus protects against disease in a mouse model. Clin Immunol 149:487497

43. Grieder FB, Vogel SN (1999) Role of interferon and interferon regulatory factors in early protection against Venezuelan equine encephalitis virus infection. Virology 257:106-118

44. Griffin DE (2007) Alphaviruses. In: Knipe DM, Howley PM (eds) Fields Virology. Lippincott, Williams \& Wilkins, Philadelphia, pp 1023-1068

45. Grivard P, Le Roux K, Laurent P, Fianu A, Perrau J, Gigan J, Hoarau G, Grondin N, Staikowsky F, Favier F, Michault A (2007) Molecular and serological diagnosis of Chikungunya virus infection. Pathol Biol (Paris) 55:490-494

46. Gupta D, Bose A, Rose W (2015) Acquired Neonatal Chikungunya Encephalopathy. Indian J Pediatr 
47. Hawman DW, Stoermer KA, Montgomery SA, Pal P, Oko L, Diamond MS, Morrison TE (2013) Chronic joint disease caused by persistent Chikungunya virus infection is controlled by the adaptive immune response. J Virol 87:13878-13888

48. Heise MT, Simpson DA, Johnston RE (2000) Sindbis-group alphavirus replication in periosteum and endosteum of long bones in adult mice. J Virol 74:9294-9299

49. Her Z, Malleret B, Chan M, Ong EK, Wong SC, Kwek DJ, Tolou H, Lin RT, Tambyah PA, Renia L, Ng LF (2010) Active infection of human blood monocytes by Chikungunya virus triggers an innate immune response. J Immunol 184:5903-5913

50. Her Z, Teng TS, Tan JJ, Teo TH, Kam YW, Lum FM, Lee WW, Gabriel C, Melchiotti R, Andiappan AK, Lulla V, Lulla A, Win MK, Chow A, Biswas SK, Leo YS, Lecuit M, Merits A, Renia L, Ng LF (2015) Loss of TLR3 aggravates CHIKV replication and pathology due to an altered virus-specific neutralizing antibody response. EMBO Mol Med 7:24-41

51. Higgs MR, Lerat H, Pawlotsky JM (2010) Downregulation of Gadd45beta expression by hepatitis $C$ virus leads to defective cell cycle arrest. Cancer Res 70:4901-4911

52. Hoarau JJ, Jaffar Bandjee MC, Krejbich Trotot P, Das T, Li-Pat-Yuen G, Dassa B, Denizot M, Guichard E, Ribera A, Henni T, Tallet F, Moiton MP, Gauzere BA, Bruniquet S, Jaffar Bandjee Z, Morbidelli P, Martigny G, Jolivet M, Gay F, Grandadam M, Tolou H, Vieillard V, Debre P, Autran B, Gasque P (2010) Persistent chronic inflammation and infection by Chikungunya arthritogenic alphavirus in spite of a robust host immune response. J Immunol 184:5914-5927

53. Jacups SP, Whelan PI, Currie BJ (2008) Ross River virus and Barmah Forest virus infections: a review of history, ecology, and predictive models, with implications for tropical northern Australia. Vector borne and zoonotic diseases 8:283-297

54. Jaffar-Bandjee MC, Ramful D, Gauzere BA, Hoarau JJ, Krejbich-Trotot P, Robin S, Ribera A, Selambarom J, Gasque P (2010) Emergence and clinical insights into the pathology of Chikungunya virus infection. Expert Rev Anti Infect Ther 8:987-996

55. Javelle E, Ribera A, Degasne I, Gauzere BA, Marimoutou C, Simon F (2015) Specific management of post-chikungunya rheumatic disorders: a retrospective study of 159 cases in Reunion Island from 2006-2012. PLoS Negl Trop Dis 9:e0003603

56. Josseran L, Paquet C, Zehgnoun A, Caillere N, Le Tertre A, Solet JL, Ledrans M (2006) Chikungunya disease outbreak, Reunion Island. Emerg Infect Dis 12:19941995

57. Joubert PE, Werneke SW, de la Calle C, Guivel-Benhassine F, Giodini A, Peduto L, Levine B, Schwartz O, Lenschow DJ, Albert ML (2012) Chikungunya virus-induced autophagy delays caspase-dependent cell death. The Journal of experimental medicine 209:1029-1047

58. Judith D, Mostowy S, Bourai M, Gangneux N, Lelek M, Lucas-Hourani M, Cayet N, Jacob Y, Prevost MC, Pierre P, Tangy F, Zimmer C, Vidalain PO, Couderc T, Lecuit M (2013) Species-specific impact of the autophagy machinery on Chikungunya virus infection. EMBO reports 14:534-544

59. Kam YW, Simarmata D, Chow A, Her Z, Teng TS, Ong EK, Renia L, Leo YS, Ng LF (2012) Early appearance of neutralizing immunoglobulin G3 antibodies is associated with chikungunya virus clearance and long-term clinical protection. J Infect Dis 205:1147-1154

60. Kelvin AA, Banner D, Silvi G, Moro ML, Spataro N, Gaibani P, Cavrini F, Pierro A, Rossini G, Cameron MJ, Bermejo-Martin JF, Paquette SG, Xu L, Danesh A, Farooqui A, Borghetto I, Kelvin DJ, Sambri V, Rubino S (2011) Inflammatory cytokine expression is associated with chikungunya virus resolution and symptom severity. PLoS Negl Trop Dis 5:e1279 
61. Krejbich-Trotot P, Denizot M, Hoarau JJ, Jaffar-Bandjee MC, Das T, Gasque P (2011) Chikungunya virus mobilizes the apoptotic machinery to invade host cell defenses. Faseb J 25:314-325

62. Kumar S, Jaffar-Bandjee MC, Giry C, Connen de Kerillis L, Merits A, Gasque P, Hoarau JJ (2012) Mouse macrophage innate immune response to Chikungunya virus infection. Virol J 9:313

63. Labadie K, Larcher T, Joubert C, Mannioui A, Delache B, Brochard P, Guigand L, Dubreil L, Lebon P, Verrier B, de Lamballerie X, Suhrbier A, Cherel Y, Le Grand R, Roques $\mathrm{P}$ (2010) Chikungunya disease in nonhuman primates involves long-term viral persistence in macrophages. J Clin Invest 120:894-906

64. Lalitha P, Rathinam S, Banushree K, Maheshkumar S, Vijayakumar R, Sathe P (2007) Ocular involvement associated with an epidemic outbreak of chikungunya virus infection. Am J Ophthalmol 144:552-556

65. Langevin HM, Cornbrooks CJ, Taatjes DJ (2004) Fibroblasts form a body-wide cellular network. Histochem Cell Biol 122:7-15

66. Larrieu S, Pouderoux N, Pistone T, Filleul L, Receveur MC, Sissoko D, Ezzedine K, Malvy D (2010) Factors associated with persistence of arthralgia among Chikungunya virus-infected travellers: report of 42 French cases. J Clin Virol 47:85-88

67. Laurent P, Le Roux K, Grivard P, Bertil G, Naze F, Picard M, Staikowsky F, Barau G, Schuffenecker I, Michault A (2007) Development of a sensitive real-time reverse transcriptase PCR assay with an internal control to detect and quantify chikungunya virus. Clin Chem 53:1408-1414

68. Lemant J, Boisson V, Winer A, Thibault L, Andre H, Tixier F, Lemercier M, Antok E, Cresta MP, Grivard P, Besnard M, Rollot O, Favier F, Huerre M, Campinos JL, Michault A (2008) Serious acute chikungunya virus infection requiring intensive care during the Reunion Island outbreak in 2005-2006. Crit Care Med 36:2536-2541

69. Lenschow DJ, Lai C, Frias-Staheli N, Giannakopoulos NV, Lutz A, Wolff T, Osiak A, Levine B, Schmidt RE, Garcia-Sastre A, Leib DA, Pekosz A, Knobeloch KP, Horak I, Virgin HWt (2007) IFN-stimulated gene 15 functions as a critical antiviral molecule against influenza, herpes, and Sindbis viruses. Proceedings of the National Academy of Sciences of the United States of America 104:1371-1376

70. Lum FM, Teo TH, Lee WW, Kam YW, Renia L, Ng LF (2013) An essential role of antibodies in the control of Chikungunya virus infection. J Immunol 190:6295-6302

71. MacDonald MR, Machlin ES, Albin OR, Levy DE (2007) The zinc finger antiviral protein acts synergistically with an interferon-induced factor for maximal activity against alphaviruses. J Virol 81:13509-13518

72. Mahendradas P, Ranganna SK, Shetty R, Balu R, Narayana KM, Babu RB, Shetty BK (2008) Ocular manifestations associated with chikungunya. Ophthalmology 115:287291

73. Mallilankaraman K, Shedlock DJ, Bao H, Kawalekar OU, Fagone P, Ramanathan AA, Ferraro B, Stabenow J, Vijayachari P, Sundaram SG, Muruganandam N, Sarangan G, Srikanth P, Khan AS, Lewis MG, Kim JJ, Sardesai NY, Muthumani K, Weiner DB (2011) A DNA vaccine against chikungunya virus is protective in mice and induces neutralizing antibodies in mice and nonhuman primates. PLoS Negl Trop Dis 5:e928

74. Malvy D, Ezzedine K, Mamani-Matsuda M, Autran B, Tolou H, Receveur MC, Pistone T, Rambert J, Moynet D, Mossalayi D (2009) Destructive arthritis in a patient with chikungunya virus infection with persistent specific IgM antibodies. BMC Infect Dis 9:200

75. Manimunda SP, Vijayachari P, Uppoor R, Sugunan AP, Singh SS, Rai SK, Sudeep AB, Muruganandam N, Chaitanya IK, Guruprasad DR (2010) Clinical progression of 
chikungunya fever during acute and chronic arthritic stages and the changes in joint morphology as revealed by imaging. Trans R Soc Trop Med Hyg 104:392-399

76. Marimoutou C, Ferraro J, Javelle E, Deparis X, Simon F (2015) Chikungunya infection: self-reported rheumatic morbidity and impaired quality of life persist 6 years later. Clin Microbiol Infect

77. Mathews JH, Roehrig JT, Trent DW (1985) Role of complement and the Fc portion of immunoglobulin $G$ in immunity to Venezuelan equine encephalomyelitis virus infection with glycoprotein-specific monoclonal antibodies. J Virol 55:594-600

78. Mavalankar D, Shastri P, Raman P (2007) Chikungunya epidemic in India: a major public-health disaster. Lancet Infect Dis 7:306-307

79. Mavalankar D, Shastri P, Bandyopadhyay T, Parmar J, Ramani KV (2008) Increased mortality rate associated with chikungunya epidemic, Ahmedabad, India. Emerg Infect Dis 14:412-415

80. Messaoudi I, Vomaske J, Totonchy T, Kreklywich CN, Haberthur K, Springgay L, Brien JD, Diamond MS, Defilippis VR, Streblow DN (2013) Chikungunya virus infection results in higher and persistent viral replication in aged rhesus macaques due to defects in anti-viral immunity. PLoS Negl Trop Dis 7:e2343

81. Milner AR, Marshall ID (1984) Pathogenesis of in utero infections with abortogenic and non-abortogenic alphaviruses in mice. J Virol 50:66-72

82. Miner JJ, Aw Yeang HX, Fox JM, Taffner S, Malkova ON, Oh ST, Kim AH, Diamond MS, Lenschow DJ, Yokoyama WM (2015) Brief report: chikungunya viral arthritis in the United States: a mimic of seronegative rheumatoid arthritis. Arthritis Rheumatol 67:1214-1220

83. Mohd Zim MA, Sam IC, Omar SF, Chan YF, AbuBakar S, Kamarulzaman A (2013) Chikungunya infection in Malaysia: comparison with dengue infection in adults and predictors of persistent arthralgia. J Clin Virol 56:141-145

84. Moro ML, Grilli E, Corvetta A, Silvi G, Angelini R, Mascella F, Miserocchi F, Sambo P, Finarelli AC, Sambri V, Gagliotti C, Massimiliani E, Mattivi A, Pierro AM, Macini P (2012) Long-term chikungunya infection clinical manifestations after an outbreak in Italy: a prognostic cohort study. J Infect 65:165-172

85. Morrison TE, Whitmore AC, Shabman RS, Lidbury BA, Mahalingam S, Heise MT (2006) Characterization of Ross River virus tropism and virus-induced inflammation in a mouse model of viral arthritis and myositis. J Virol 80:737-749

86. Morrison TE, Oko L, Montgomery SA, Whitmore AC, Lotstein AR, Gunn BM, Elmore SA, Heise MT (2011) A mouse model of chikungunya virus-induced musculoskeletal inflammatory disease: evidence of arthritis, tenosynovitis, myositis, and persistence. Am J Pathol 178:32-40

87. Morrison TE (2014) Reemergence of chikungunya virus. J Virol 88:11644-11647

88. Nakaya HI, Gardner J, Poo YS, Major L, Pulendran B, Suhrbier A (2012) Gene profiling of Chikungunya virus arthritis in a mouse model reveals significant overlap with rheumatoid arthritis. Arthritis Rheum 64:3553-3563

89. Narsimulu G, Prabhu N (2011) Post-chikungunya chronic arthritis. J Assoc Physicians India 59:81

90. Ng LF, Chow A, Sun YJ, Kwek DJ, Lim PL, Dimatatac F, Ng LC, Ooi EE, Choo KH, Her Z, Kourilsky P, Leo YS (2009) IL-1beta, IL-6, and RANTES as biomarkers of Chikungunya severity. PLoS One 4:e4261

91. Nitatpattana N, Kanjanopas K, Yoksan S, Satimai W, Vongba N, Langdatsuwan S, Nakgoi K, Ratchakum S, Wauquier N, Souris M, Auewarakul P, Gonzalez JP (2014) Long-term persistence of Chikungunya virus neutralizing antibodies in human populations of North Eastern Thailand. Virol J 11:183 
92. Ozden S, Huerre M, Riviere JP, Coffey LL, Afonso PV, Mouly V, de Monredon J, Roger JC, El Amrani M, Yvin JL, Jaffar MC, Frenkiel MP, Sourisseau M, Schwartz O, Butler-Browne G, Despres P, Gessain A, Ceccaldi PE (2007) Human muscle satellite cells as targets of Chikungunya virus infection. PLoS One 2:e527

93. Pal P, Dowd KA, Brien JD, Edeling MA, Gorlatov S, Johnson S, Lee I, Akahata W, Nabel GJ, Richter MK, Smit JM, Fremont DH, Pierson TC, Heise MT, Diamond MS (2013) Development of a highly protective combination monoclonal antibody therapy against Chikungunya virus. PLoS Pathog 9:e1003312

94. Palha N, Guivel-Benhassine F, Briolat V, Lutfalla G, Sourisseau M, Ellett F, Wang CH, Lieschke GJ, Herbomel P, Schwartz O, Levraud JP (2013) Real-time whole-body visualization of Chikungunya Virus infection and host interferon response in zebrafish. PLoS Pathog 9:e1003619

95. Panning M, Grywna K, van Esbroeck M, Emmerich P, Drosten C (2008) Chikungunya fever in travelers returning to Europe from the Indian Ocean region, 2006. Emerg Infect Dis 14:416-422

96. Parola P, de Lamballerie X, Jourdan J, Rovery C, Vaillant V, Minodier P, Brouqui P, Flahault A, Raoult D, Charrel RN (2006) Novel chikungunya virus variant in travelers returning from Indian Ocean islands. Emerg Infect Dis 12:1493-1499

97. Partidos CD, Weger J, Brewoo J, Seymour R, Borland EM, Ledermann JP, Powers AM, Weaver SC, Stinchcomb DT, Osorio JE (2011) Probing the attenuation and protective efficacy of a candidate chikungunya virus vaccine in mice with compromised interferon (IFN) signaling. Vaccine 29:3067-3073

98. Pialoux G, Gauzere BA, Jaureguiberry S, Strobel M (2007) Chikungunya, an epidemic arbovirosis. Lancet Infect Dis 7:319-327

99. Poo YS, Nakaya H, Gardner J, Larcher T, Schroder WA, Le TT, Major LD, Suhrbier A (2014) CCR2 deficiency promotes exacerbated chronic erosive neutrophildominated chikungunya virus arthritis. J Virol 88:6862-6872

100. Poo YS, Rudd PA, Gardner J, Wilson JA, Larcher T, Colle MA, Le TT, Nakaya HI, Warrilow D, Allcock R, Bielefeldt-Ohmann H, Schroder WA, Khromykh AA, Lopez JA, Suhrbier A (2014) Multiple immune factors are involved in controlling acute and chronic chikungunya virus infection. PLoS Negl Trop Dis 8:e3354

101. Queyriaux B, Simon F, Grandadam M, Michel R, Tolou H, Boutin JP (2008) Clinical burden of chikungunya virus infection. Lancet Infect Dis 8:2-3

102. Rajapakse S, Rodrigo C, Rajapakse A (2010) Atypical manifestations of chikungunya infection. Trans R Soc Trop Med Hyg 104:89-96

103. Ramful D, Carbonnier M, Pasquet M, Bouhmani B, Ghazouani J, Noormahomed T, Beullier G, Attali T, Samperiz S, Fourmaintraux A, Alessandri JL (2007) Mother-tochild transmission of Chikungunya virus infection. Pediatr Infect Dis J 26:811-815

104. Rampal, Sharda M, Meena H (2007) Neurological complications in Chikungunya fever. J Assoc Physicians India 55:765-769

105. Reddy V, Mani RS, Desai A, Ravi V (2014) Correlation of plasma viral loads and presence of Chikungunya IgM antibodies with cytokine/chemokine levels during acute Chikungunya virus infection. J Med Virol 86:1393-1401

106. Roques P, Gras G (2011) Chikungunya fever: focus on peripheral markers of pathogenesis. J Infect Dis 203:141-143

107. Rosario V, Munoz-Louis R, Valdez T, Adames S, Medrano J, Paulino I, Paula J, AlbaFeriz R (2015) Chikungunya infection in the general population and in patients with rheumatoid arthritis on biological therapy. Clin Rheumatol

108. Rudd PA, Wilson J, Gardner J, Larcher T, Babarit C, Le TT, Anraku I, Kumagai Y, Loo YM, Gale M, Jr., Akira S, Khromykh AA, Suhrbier A (2012) Interferon response 
factors 3 and 7 protect against Chikungunya virus hemorrhagic fever and shock. $\mathbf{J}$ Virol 86:9888-9898

109. Rulli NE, Rolph MS, Srikiatkhachorn A, Anantapreecha S, Guglielmotti A, Mahalingam S (2011) Protection from arthritis and myositis in a mouse model of acute chikungunya virus disease by bindarit, an inhibitor of monocyte chemotactic protein-1 synthesis. J Infect Dis 204:1026-1030

110. Ryman KD, Klimstra WB, Nguyen KB, Biron CA, Johnston RE (2000) Alpha/beta interferon protects adult mice from fatal Sindbis virus infection and is an important determinant of cell and tissue tropism. J Virol 74:3366-3378

111. Schilte C, Couderc T, Chretien F, Sourisseau M, Gangneux N, Guivel-Benhassine F, Kraxner A, Tschopp J, Higgs S, Michault A, Arenzana-Seisdedos F, Colonna M, Peduto L, Schwartz O, Lecuit M, Albert ML (2010) Type I IFN controls chikungunya virus via its action on nonhematopoietic cells. The Journal of experimental medicine 207:429-442

112. Schilte C, Buckwalter MR, Laird ME, Diamond MS, Schwartz O, Albert ML (2012) Cutting edge: independent roles for IRF-3 and IRF-7 in hematopoietic and nonhematopoietic cells during host response to Chikungunya infection. J Immunol 188:2967-2971

113. Schilte C, Staikowsky F, Couderc T, Madec Y, Carpentier F, Kassab S, Albert ML, Lecuit M, Michault A (2013) Chikungunya virus-associated long-term arthralgia: a 36-month prospective longitudinal study. PLoS Negl Trop Dis 7:e2137

114. Schmaljohn AL, Kokubun KM, Cole GA (1983) Protective monoclonal antibodies define maturational and $\mathrm{pH}$-dependent antigenic changes in Sindbis virus E1 glycoprotein. Virology 130:144-154

115. Schuffenecker I, Iteman I, Michault A, Murri S, Frangeul L, Vaney MC, Lavenir R, Pardigon N, Reynes JM, Pettinelli F, Biscornet L, Diancourt L, Michel S, Duquerroy S, Guigon G, Frenkiel MP, Brehin AC, Cubito N, Despres P, Kunst F, Rey FA, Zeller $\mathrm{H}$, Brisse S (2006) Genome microevolution of chikungunya viruses causing the Indian Ocean outbreak. PLoS Med 3:e263

116. Schwartz O, Albert ML (2010) Biology and pathogenesis of chikungunya virus. Nature reviews Microbiology 8:491-500

117. Scott DL, Wolfe F, Huizinga TW (2010) Rheumatoid arthritis. Lancet 376:1094-1108

118. Selvarajah S, Sexton NR, Kahle KM, Fong RH, Mattia KA, Gardner J, Lu K, Liss NM, Salvador B, Tucker DF, Barnes T, Mabila M, Zhou X, Rossini G, Rucker JB, Sanders DA, Suhrbier A, Sambri V, Michault A, Muench MO, Doranz BJ, Simmons G (2013) A neutralizing monoclonal antibody targeting the acid-sensitive region in chikungunya virus E2 protects from disease. PLoS Negl Trop Dis 7:e2423

119. Simon F, Parola P, Grandadam M, Fourcade S, Oliver M, Brouqui P, Hance P, Kraemer P, Ali Mohamed A, de Lamballerie X, Charrel R, Tolou H (2007) Chikungunya infection: an emerging rheumatism among travelers returned from Indian Ocean islands. Report of 47 cases. Medicine (Baltimore) 86:123-137

120. Singh SS, Manimunda SP, Sugunan AP, Sahina, Vijayachari P (2008) Four cases of acute flaccid paralysis associated with chikungunya virus infection. Epidemiol Infect 136:1277-1280

121. Sissoko D, Malvy D, Ezzedine K, Renault P, Moscetti F, Ledrans M, Pierre V (2009) Post-epidemic Chikungunya disease on Reunion Island: course of rheumatic manifestations and associated factors over a 15-month period. PLoS Negl Trop Dis 3:e389 
122. Sissoko D, Ezzedine K, Moendandze A, Giry C, Renault P, Malvy D (2010) Field evaluation of clinical features during chikungunya outbreak in Mayotte, 2005-2006. Trop Med Int Health 15:600-607

123. Sourisseau M, Schilte C, Casartelli N, Trouillet C, Guivel-Benhassine F, Rudnicka D, Sol-Foulon N, Le Roux K, Prevost MC, Fsihi H, Frenkiel MP, Blanchet F, Afonso PV, Ceccaldi PE, Ozden S, Gessain A, Schuffenecker I, Verhasselt B, Zamborlini A, Saib A, Rey FA, Arenzana-Seisdedos F, Despres P, Michault A, Albert ML, Schwartz O (2007) Characterization of reemerging chikungunya virus. PLoS Pathog 3:e89

124. Staikowsky F, Talarmin F, Grivard P, Souab A, Schuffenecker I, Le Roux K, Lecuit M, Michault A (2009) Prospective study of Chikungunya virus acute infection in the Island of La Reunion during the 2005-2006 outbreak. PLoS One 4:e7603

125. Staples JE, Breiman RF, Powers AM (2009) Chikungunya fever: an epidemiological review of a re-emerging infectious disease. Clin Infect Dis 49:942-948

126. Suhrbier A, Jaffar-Bandjee MC, Gasque P (2012) Arthritogenic alphaviruses--an overview. Nat Rev Rheumatol 8:420-429

127. Tandale BV, Sathe PS, Arankalle VA, Wadia RS, Kulkarni R, Shah SV, Shah SK, Sheth JK, Sudeep AB, Tripathy AS, Mishra AC (2009) Systemic involvements and fatalities during Chikungunya epidemic in India, 2006. J Clin Virol 46:145-149

128. Teng TS, Foo SS, Simamarta D, Lum FM, Teo TH, Lulla A, Yeo NK, Koh EG, Chow A, Leo YS, Merits A, Chin KC, Ng LF (2012) Viperin restricts chikungunya virus replication and pathology. J Clin Invest 122:4447-4460

129. Teo TH, Lum FM, Lee WW, Ng LF (2012) Mouse models for Chikungunya virus: deciphering immune mechanisms responsible for disease and pathology. Immunol Res 53:136-147

130. Teo TH, Lum FM, Claser C, Lulla V, Lulla A, Merits A, Renia L, Ng LF (2013) A pathogenic role for $\mathrm{CD} 4+\mathrm{T}$ cells during Chikungunya virus infection in mice. $\mathrm{J}$ Immunol 190:259-269

131. Teo TH, Her Z, Tan JJ, Lum FM, Lee WW, Chan YH, Ong RY, Kam YW, LeparcGoffart I, Gallian P, Renia L, de Lamballerie X, Ng LF (2015) Caribbean and La Reunion Chikungunya virus isolates differ in their capacity to induce proinflammatory Th1 and NK cell responses and acute joint pathology. J Virol

132. Thiberville SD, Boisson V, Gaudart J, Simon F, Flahault A, de Lamballerie X (2013) Chikungunya fever: a clinical and virological investigation of outpatients on Reunion Island, South-West Indian Ocean. PLoS Negl Trop Dis 7:e2004

133. Thiberville SD, Moyen N, Dupuis-Maguiraga L, Nougairede A, Gould EA, Roques P, de Lamballerie X (2013) Chikungunya fever: epidemiology, clinical syndrome, pathogenesis and therapy. Antiviral Res 99:345-370

134. Thon-Hon VG, Denizot M, Li-Pat-Yuen G, Giry C, Jaffar-Bandjee MC, Gasque P (2012) Deciphering the differential response of two human fibroblast cell lines following Chikungunya virus infection. Virol J 9:213

135. Valamparampil JJ, Chirakkarot S, Letha S, Jayakumar C, Gopinathan KM (2009) Clinical profile of Chikungunya in infants. Indian J Pediatr 76:151-155

136. Venkatesan A, Tunkel AR, Bloch KC, Lauring AS, Sejvar J, Bitnun A, Stahl JP, Mailles A, Drebot M, Rupprecht CE, Yoder J, Cope JR, Wilson MR, Whitley RJ, Sullivan J, Granerod J, Jones C, Eastwood K, Ward KN, Durrheim DN, Solbrig MV, Guo-Dong L, Glaser CA (2013) Case definitions, diagnostic algorithms, and priorities in encephalitis: consensus statement of the international encephalitis consortium. Clin Infect Dis 57:1114-1128

137. Venugopalan A, Ghorpade RP, Chopra A (2014) Cytokines in acute chikungunya. PLoS One 9:e111305 
138. Wang R, Wang J, Acharya D, Paul AM, Bai F, Huang F, Guo YL (2014) Antiviral responses in mouse embryonic stem cells: differential development of cellular mechanisms in type I interferon production and response. J Biol Chem 289:2518625198

139. Wauquier N, Becquart P, Nkoghe D, Padilla C, Ndjoyi-Mbiguino A, Leroy EM (2011) The acute phase of Chikungunya virus infection in humans is associated with strong innate immunity and T CD8 cell activation. J Infect Dis 204:115-123

140. Weaver SC, Forrester NL (2015) Chikungunya: Evolutionary history and recent epidemic spread. Antiviral Res 120:32-39

141. Weaver SC, Lecuit M (2015) Chikungunya virus and the global spread of a mosquitoborne disease. N Engl J Med 372:1231-1239

142. Werneke SW, Schilte C, Rohatgi A, Monte KJ, Michault A, Arenzana-Seisdedos F, Vanlandingham DL, Higgs S, Fontanet A, Albert ML, Lenschow DJ (2011) ISG15 is critical in the control of Chikungunya virus infection independent of UbE1L mediated conjugation. PLoS Pathog 7:e1002322

143. White LK, Sali T, Alvarado D, Gatti E, Pierre P, Streblow D, Defilippis VR (2011) Chikungunya virus induces IPS-1-dependent innate immune activation and protein kinase R-independent translational shutoff. J Virol 85:606-620

144. Wielanek AC, Monredon JD, Amrani ME, Roger JC, Serveaux JP (2007) GuillainBarre syndrome complicating a Chikungunya virus infection. Neurology 69:21052107

145. Win MK, Chow A, Dimatatac F, Go CJ, Leo YS (2010) Chikungunya fever in Singapore: acute clinical and laboratory features, and factors associated with persistent arthralgia. J Clin Virol 49:111-114

146. Wu J, Wang J, Li M, Yang Y, Wang B, Zheng YG (2011) Small molecule inhibitors of histone acetyltransferase Tip60. Bioorg Chem 39:53-58

147. Zacks MA, Paessler S (2010) Encephalitic alphaviruses. Vet Microbiol 140:281-286

148. Zare F, Bokarewa M, Nenonen N, Bergstrom T, Alexopoulou L, Flavell RA, Tarkowski A (2004) Arthritogenic properties of double-stranded (viral) RNA. J Immunol 172:5656-5663

149. Zhang Y, Burke CW, Ryman KD, Klimstra WB (2007) Identification and characterization of interferon-induced proteins that inhibit alphavirus replication. $\mathrm{J}$ Virol 81:11246-11255

150. Ziegler SA, Lu L, da Rosa AP, Xiao SY, Tesh RB (2008) An animal model for studying the pathogenesis of chikungunya virus infection. Am J Trop Med Hyg 79:133-139 